\title{
EKSTRAKSI DRY RENDERING DAN KARAKTERISASI MINYAK IKAN PATIN (Pangasius sp.) HASIL SAMPING INDUSTRI FILET DI LAMPUNG
}

\author{
Sugeng Heri Suseno ${ }^{\star}$, Ahmad Khoirudin Rizkon, Agoes Mardiono Jacoeb, \\ Nurjanah, Pipin Supinah \\ Departemen Teknologi Hasil Perairan, Fakultas Perikanan dan Ilmu Kelautan, Institut Pertanian Bogor, \\ Kampus IPB Darmaga, Jalan Agatis, Bogor 16680, Jawa Barat \\ ^Korespondensi: sug_thp@yahoo.com \\ Diterima: 8 Januari 2020/Disetujui: 24 April 2020
}

Cara sitasi: Suseno SH, Riskon AK, Jacoeb AM, Nurjanah, Supinah P. 2020. Ekstraksi dry rendering dan karakterisasi minyak ikan patin (Pangasius sp.) hasil samping industri filet di Lampung. Jurnal Pengolahan Hasil Perikanan Indonesia. 23(1): 38-46.

\begin{abstract}
Abstrak
Produksi minyak ikan di Indonesia memiliki kualitas rendah dan hanya dimanfaatkan sebagai bahan tambahan pakan ternak. Tingginya suhu dan lamanya ekstraksi memicu pembentukan radikal bebas dan oksidasi pada minyak sehingga memengaruhi kualitas minyak yang dihasilkan. Perbaikan proses ekstraksi mampu menghasilkan minyak ikan dengan kualitas baik. Tujuan penelitian ini adalah untuk menentukan suhu dan waktu ekstraksi untuk menghasilkan minyak ikan sesuai standar IFOS dengan metode dry rendering. Ekstraksi dilakukan pada suhu 50,60,70 ${ }^{\circ} \mathrm{C}$ dan waktu 1, 2, 3 jam dengan metode dry rendering. Hasil ekstraksi terbaik yaitu pada suhu $50^{\circ} \mathrm{C}, 2$ jam dan selanjutnya dilakukan pemurnian dengan proses bleaching menggunakan magnesol XL. Minyak ikan yang dihasilkan memiliki asam lemak bebas $0,08 \pm 0,03 \%$, p-anisidin 1,92 $\pm 0,63 \mathrm{mEq} \mathrm{kg}^{-1}$, total oksidasi 7,48 $\pm 0,23 \mathrm{mEq} \mathrm{kg} \mathrm{kg}^{-1}$ dan bilangan peroksida $2,70 \pm 0,20$ $\mathrm{mEq} / \mathrm{kg}$. Hasil penelitian menunjukkan bahwa minyak ikan memenuhi standar IFOS pada parameter asam lemak bebas $(\leq 1,5 \%)$, bilangan p-anisidin $\left(\leq 20,0\right.$ meq $\left.\mathrm{kg}^{-1}\right)$, total oksidasi $\left(\leq 26,0 \mathrm{meq} \mathrm{kg}{ }^{-1}\right)$ dan bilangan peroksida $\left(\leq 5,0 \mathrm{meq} \mathrm{kg}^{-1}\right)$.
\end{abstract}

Kata kunci: dry rendering, IFOS, minyak ikan, suhu, waktu.

\section{Extraction with Dry Rendering Method and Characterization of Fish Oil by-Product of Pangasius Fillet Industries In Lampung}

\begin{abstract}
Fish oil in Indonesia was produced in low quality and used as an additional ingredient for animal feed. The high temperature and the length of extraction period lead to the formation of free radicals and oxidation in oil which affects the quality of the oil produced. Improvement of the extraction process will produce a good quality fish oil. The purpose of this study was to determine the temperature and extraction period to produce fish oil according to IFOS standard by dry rendering method. Extraction was carried out at temperatures of $50,60,70^{\circ} \mathrm{C}$ for $1,2,3$ hours with the dry rendering method. The best extraction method was at a temperature of $50^{\circ} \mathrm{C}$ for 2 hours and then carried out purification with bleaching process of magnesol XL. The fish oil produced had FFA, $\mathrm{p}$-anisidin value, total oxidation, and peroxide value, respectively was $0.08 \pm 0.03 \%, 1.92 \pm 0.63 \mathrm{mEq} \mathrm{kg}^{-1}, 7.48 \pm 0.23 \mathrm{mEq} \mathrm{kg}{ }^{-1}, 2.70 \pm 0.20 \mathrm{mEq} \mathrm{kg}^{-1}$. The results showed that fish oil met IFOS standard on free fatty acid parameters $(\leq 1.5 \%)$, p-anisidin value $\left(\leq 20.0 \mathrm{meq} \mathrm{kg}^{-1}\right)$, total oxidation $(\leq 26.0$ meq $\left.\mathrm{kg}^{-1}\right)$ and peroxide value $\left(\leq 5.0 \mathrm{meq} \mathrm{kg}^{-1}\right)$.
\end{abstract}

Keywords: dry rendering, fish oil, IFOS, period, temperature

\section{PENDAHULUAN}

Ikan patin merupakan komoditas perikanan budidaya dengan potensi pasar yang cukup menjanjikan. Produksi ikan patin tahun 2017 mencapai 437.111 ton dan naik 21,9\% dibandingkan tahun 2016 (KKP 2018). Meningkatnya nilai produksi ikan patin memicu adanya produksi dalam bentuk olahan, salah satunya filet ikan. Proses pengolahan filet ikan ini menghasilkan produk samping sebesar $67 \%$ yang terdiri atas kepala, ekor, kulit, dan jeroan. Berdasarkan jumlah tersebut dan data produksi ikan patin tahun 2017, jika hanya dimanfaatkan dagingnya maka hasil samping produk filet ikan patin dapat mencapai 292.864 ton. Pemanfaatan hasil samping filet ikan dapat dioptimalkan sesuai dengan bagiannya masing-masing, di 
antaranya lemak jeroan ikan patin menjadi minyak ikan yang dapat memberikan nilai tambah.

Minyak ikan patin mengandung omega 3 rendah namun tinggi kandungan omega 6 dan omega 9 (Orban et al. 2008; Thammapat et al. 2010). Omega 6 yaitu asam lemak esensial yang berperan untuk membentuk trombosit, memelihara membran sel, dan menjaga keseimbangan kolesterol (Harris et al. 2009). Asam lemak non esensial omega 9 yang merupakan asam lemak tak jenuh tunggal ini berperan dalam menurunkan kolesterol jahat (LDL) dan meningkatkan kolesterol baik (HDL) dalam darah (Felix dan Velazquez 2002). Hal ini menyebabkan minyak ikan menjadi salah satu produk perikanan dengan permintaan yang tinggi untuk dijadikan sebagai suplemen makanan, shortening, dan bahan industri lainnya. Namun, kebutuhan minyak ikan di Indonesia masih belum tercukupi, hal ini dibuktikan dengan volume impor minyak ikan di Indonesia pada tahun 2017 mencapai $10.056 .744 \mathrm{~kg}$ setara dengan 17.171.098 USD, sedangkan volume ekspor minyak ikan $338.932 \mathrm{~kg}$ setara dengan 1.834.517 USD (BPS 2017).

Ketergantungan impor minyak ikan tersebut dipengaruhi oleh rendahnya produksi minyak ikan di Indonesia serta belum optimalnya dalam memproduksi minyak ikan yang sesuai standar (Maulana et al. 2014). Hastarini et al. (2012) mengkarakterisasi minyak ikan dari isi perut patin jambal dengan metode ekstraksi wet rendering pada suhu $70^{\circ} \mathrm{C}$ selama 15 menit, memiliki nilai peroksida 7,7 mEq kg-1. Kamini et al. (2016) melakukan ektraksi dry rendering dengan menggunakan lemak jeroan hasil samping pengolahan salai patin siam (Pangasius hypothalmus) pada suhu $70^{\circ} \mathrm{C}$ selama 2 jam, memiliki nilai peroksida $15 \mathrm{mEq} \mathrm{kg}^{-1}$ dan total oksidasi $40 \mathrm{mEq} \mathrm{kg}$.

Kualitas minyak ikan dapat ditentukan berdasarkan International Fish Oil Standards (IFOS) yang meliputi bilangan asam lemak bebas $\leq 1,50 \%$, bilangan asam $\leq 3,00 \mathrm{mg}$ $\mathrm{KOH} \mathrm{g}^{-1}$, nilai peroksida $\leq 5,00 \mathrm{mEq} \mathrm{kg}^{-1}$, nilai anisidin $\leq 20,00 \mathrm{mEq} \mathrm{kg}{ }^{-1}$, dan total oksidasi $\leq 26,00 \mathrm{mEq} \mathrm{kg}^{-1}$ (IFOS 2014). Sejauh ini penelitian mengenai metode ekstraksi dengan suhu dan waktu berbeda pada minyak ikan air tawar yang sesuai standar IFOS belum banyak dilakukan. Penelitian ini memiliki tujuan menentukan suhu dan waktu ekstraksi terbaik dengan metode dry rendering yang mampu menghasilkan minyak ikan dengan nilai asam lemak bebas (FFA), bilangan peroksida (PV), bilangan anisidin (p-anisidin), dan total oksidasi (TOTOX) yang sesuai standar IFOS (2014) serta hasil ekstraksi minyak ikan yang belum sesuai perlu dilakukan pemurnian sesuai karakteristiknya untuk mendapatkan kualitas minyak ikan sesuai IFOS (2014).

\section{BAHAN DAN METODE Bahan dan Alat}

Bahan utama yang digunakan yaitu lemak jeroan ikan patin hasil samping industri filet PT Pond Site Central Pertiwi Bahari, Kabupaten Tulangbawang Lampung. Bahan kimia yang digunakan adalah larutan standar SupelcoTM37 Component Fatty Acid Methy Ester (FAME) mix, larutan natrium hidroksida ( $\mathrm{NaOH})$ 0,5 mL dalam metanol, $\mathrm{BF}_{3} 20 \%$, natrium klorida $(\mathrm{NaCl})$ jenuh, asam asetat, kloroform, kalium iodida (KI) jenuh, akuades, larutan pati $1 \%$, larutan $\mathrm{Na}_{2} \mathrm{~S}_{2} \mathrm{O}_{3}$ $0,01 \%$, asam asetat glasial, larutan isooktan, alkohol 95\%, indikator fenolftalein, $\mathrm{KOH}$ $0,1 \mathrm{~N}$ dan magnesol XL 5\% (b/b). Peralatan yang digunakan untuk ekstraksi adalah heat and drying oven tipe ME-DHG series, loyang, timbangan digital (Chq. Taiwan, 0,01 gram), botol kedap cahaya. Alat yang digunakan dalam analisis profil asam lemak adalah GC-MS (Gas Chromatography Mass Spectrometry) tipe Shimadzu 2010 Plus standar SupelcoTM37 Component FAME Mix, semprit $10 \mathrm{~mL}$, kompor listrik (Maspion, Jepang), dan alat yang digunakan untuk pengujian bilangan peroksida, $\mathrm{p}$-anisidin, nilai asam lemak bebas adalah pipet mikro dan buret (Pyrex, Jerman), labu Erlenmeyer (Iwaki), beaker glass, gelas ukur, pipet volumetrik, bulb, alat titrasi, kompor listrik (Maspion, Jepang), perangkat spektrofotometer UVVIS. Alat yang digunakan untuk pemurnian adalah magnetic stirrer (CORNING PC-4200), sentrifuge (Himac CR21G, Hitachi, Japan), labu Erlenmeyer (Iwaki), timbangan (Chq. Taiwan, 0,01 gram) dan gelas ukur. 


\section{Metode Penelitian}

Penelitian ini dilakukan melalui tiga tahapan. Tahap pertama yaitu ekstraksi yang mengacu pada Damongilala (2008) dengan modifikasi pada waktu 1, 2, 3 jam dan suhu 50, $60,70^{\circ} \mathrm{C}$ menggunakan metode dry rendering. Ekstraksi dilakukan dengan cara pemanasan dalam oven di rak bagian atas. Tahap kedua yaitu karakterisasi oksidasi yang meliputi bilangan peroksida (AOAC 2005), p-anisidin (IUPAC 1987), nilai asam lemak bebas (AOCS 1998), dan total oksidasi (AOCS 1997), selain itu juga dilakukan perhitungan rendemen dan pengujian profil asam lemak (AOAC 2005). Tahap ketiga yaitu pemurnian minyak ikan hasil ekstraksi terbaik sesuai karakteristik oksidasi yang masih belum sesuai standar. Pemurnian ini dilakukan dengan proses bleaching menggunakan magnesol XL yang mengacu pada Suseno et al. (2011) dengan perlakuan 5\% (b/b). Data yang diperoleh dari hasil penelitian berupa tabel, gambar dan diagram batang yang dilakukan analisis secara deskriptif. Data ratarata dan standar deviasi parameter oksidasi minyak ikan diolah menggunakan perangkat lunak Microsoft Excel 2013.

\section{HASIL DAN PEMBAHASAN Rendemen Minyak Ikan}

Persentase rendemen mengalami peningkatan seiring meningkatnya suhu dan lamanya waktu ekstraksi (Figure 1). Persentase rendemen tertinggi diperoleh pada perlakuan suhu $70^{\circ} \mathrm{C}$ berkisar 62,01-76,07\%. Hasil rendemen yang dihasilkan tidak berbeda jauh dengan Kamini et al. (2016) yang mengekstraksi lemak patin pada suhu $70^{\circ} \mathrm{C}$ diperoleh rendemen berkisar 72,50-76,43\%. $\mathrm{Wu}$ dan Peter (2008) menyatakan bahwa rendemen minyak yang dihasilkan salah satunya dipengaruhi oleh suhu. Pemanasan menyebabkan denaturasi protein sehingga minyak dapat keluar (Nugroho et al. 2014), sedangkan pada suhu tinggi menyebabkan kerusakan protein, sehingga dapat mudah ditembus oleh minyak yang mengakibatkan minyak yang keluar semakin banyak (Estiasih 2009). Begitu juga dengan lama waktu ekstraksi maka minyak yang terekstrak semakin banyak, akibat dari pecahnya sel adiposa (Estiasih 2009).

\section{Asam Lemak Bebas}

Asam lemak bebas atau free fatty acid (FFA) berada pada golongan asam bebas dan tidak terikat dari trigliserida (Ketaren 2012). Asam lemak bebas menjadi parameter dalam penentuan kualitas minyak ikan yang dihasilkan. Hasil karakterisasi asam lemak bebas menunjukkan bahwa terjadi penurunan seiring peningkatan suhu dan lama waktu ekstraksi (Figure 2). Asam lemak bebas pada minyak ikan patin hasil ekstraksi sudah sesuai dengan IFOS (2014) yaitu $\leq 1,5 \%$. Nilai asam lemak bebas yang dihasilkan berada pada interval $0,07-0,24 \%$. Nilai asam lemak bebas yang rendah diduga akibat tingginya komposisi profil asam lemak SFA dan MUFA dibanding PUFA sehingga minyak lebih stabil. Hal ini selaras dengan pernyataan Sartika (2009) bahwa minyak yang didominasi asam oleat tidak mudah mengalami kerusakan pada pemanasan mencapai $200^{\circ} \mathrm{C}$. Di sisi lain, akibat hilangnya komponen volatil

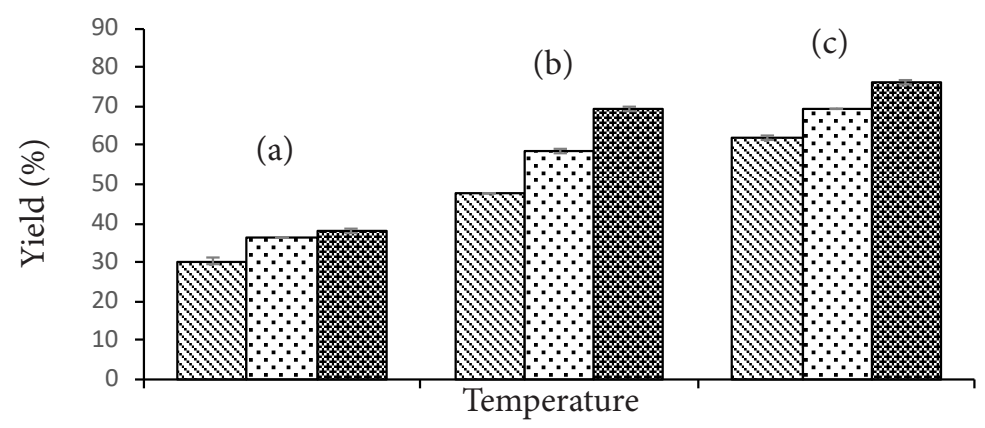

Figure 1 Effect of temperature and time on the yield of fish oil extraction using dry rendering method; (a) $50^{\circ} \mathrm{C}$; (b) $60^{\circ} \mathrm{C}$; (c) $70^{\circ} \mathrm{C}$; $\mathrm{N}$ one hour; two hour; three hour. 


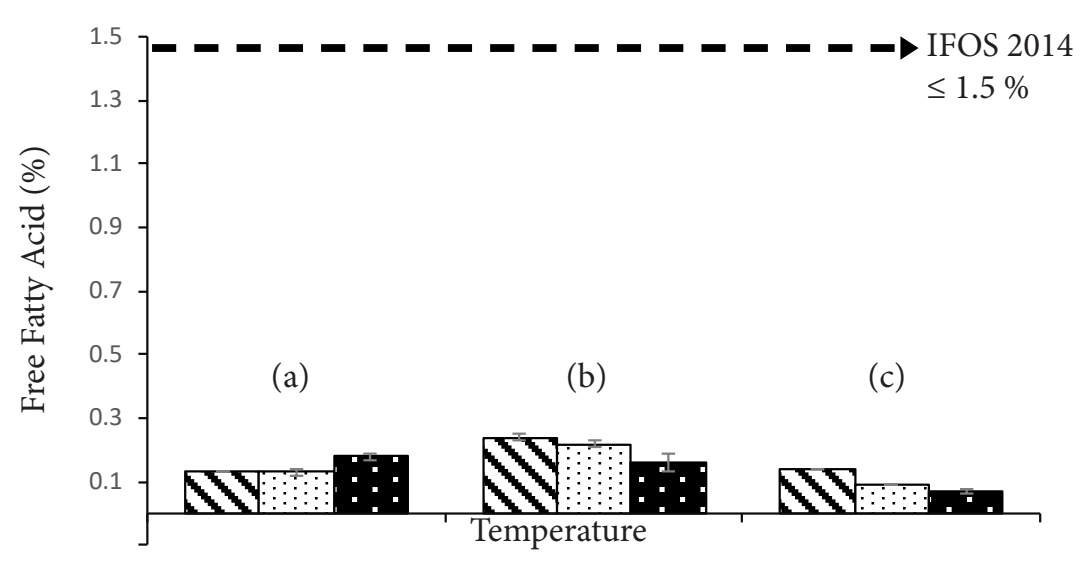

Figure 2 Effect of temperature and time on the free fatty acid of fish oil extraction from dry rendering;

(a) $50^{\circ} \mathrm{C}$; (b) $60^{\circ} \mathrm{C}$; (c) $70^{\circ} \mathrm{C}$; $\mathbb{N}$ one hour; two hour; three hour.

hidrokarbon yang disebabkan oleh proses pemisahan rantai karbon asam lemak dan oksidasi termal dari asam lemak tidak jenuh akibat proses pemanasan. Suhu ekstraksi yang tinggi mampu mendenaturasi enzim lipase yang mampu mencegah lepasnya komponen asam lemak bebas (Weber et al. 2007). Hal ini juga didapati dalam penelitian Chantachum et al. (2000) dengan penggunaan suhu ekstraksi $95^{\circ} \mathrm{C}$ pada minyak ikan tuna diperoleh nilai FFA paling rendah.

\section{Bilangan Peroksida}

Pengukuran bilangan peroksida minyak ikan bertujuan menentukan kandungan hidroperoksidanya yang merupakan produk oksidasi primer. Kandungan hidroperoksida yang semakin tinggi menunjukkan kemunduran mutu minyak. Hidroperoksida diduga terbentuk akibat asam lemak tidak jenuh yang berikatan dengan oksigen bebas (Memon et al. 2010). Proses ini terjadi berlangsung secara cepat apabila ada faktorfaktor pendukungnya, seperti suhu dan cahaya (Suseno et al. 2015). Bilangan peroksida meningkat seiring kenaikan suhu dan lama waktu ekstraksi (Figure 3). Hal ini diduga suhu yang semakin tinggi dan lama waktu ekstraksi menyebabkan oksigen yang terlarut dalam bahan semakin sedikit. Penyebabnya adalah meningkatnya gerakan molekul pada minyak, sehingga dapat menyebabkan struktur heksagonal hancur, oksigen yang terperangkap menjadi lepas dan sebaliknya (Yoshiara 2013). Nilai bilangan peroksida terendah diperoleh pada ekstraksi dengan suhu $50 \mathrm{oC}$ selama 2 jam yaitu $5,75 \mathrm{mEq} / \mathrm{kg}$, namun tidak berbeda nyata terhadap bilangan peroksida pada ekstraksi suhu $50 \mathrm{oC}$ selama 1 jam yaitu $6,26 \mathrm{mEq} / \mathrm{kg}$. Nilai peroksida

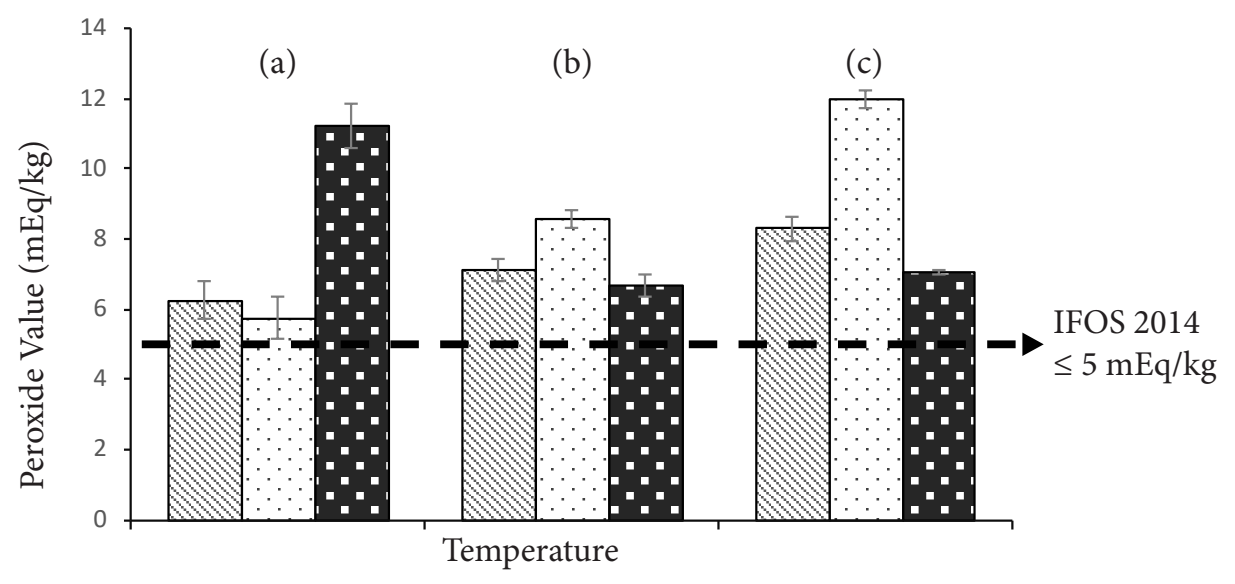

Figure 3 Effect of temperature and time on the proxide value of fish oil extraction using dry rendering method; (a) $50^{\circ} \mathrm{C}$; (b) $60^{\circ} \mathrm{C}$; (c) $70^{\circ} \mathrm{C}$; $\mathbb{N}$ one hour; two hour; three hour. 


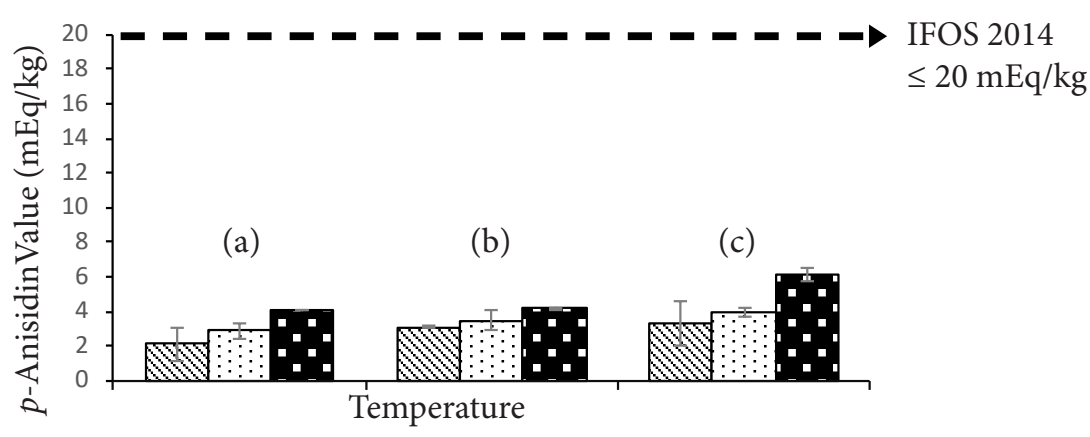

Figure 4 Effect of temperature and time on the anisidine value of fish oil extraction using dry rendering method; (a) $50^{\circ} \mathrm{C}$; (b) $60^{\circ} \mathrm{C}$; (c) $70^{\circ} \mathrm{C}$; $\mathrm{N}$ one hour; two hour; three hour.

minyak ikan yang diperoleh belum memenuhi standar IFOS (2014) yaitu $\leq 5 \mathrm{mEq} / \mathrm{kg}$. Penurunan nilai peroksida yang terjadi pada suhu $50^{\circ} \mathrm{C}$ selama 2 jam diduga akibat lamanya waktu dan rendahnya suhu sehingga mampu menghambat terlarutnya oksigen dalam minyak (Estiasih 2009).

\section{Bilangan $p$-Anisidin}

Bilangan p-anisidin menunjukkan kualitas mutu minyak ikan akibat oksidasi sekunder (Estiasih 2009). Proses oksidasi terjadi oleh degradasi lemak lanjutan yang menghasilkan senyawa hidroperoksida. Dekomposisi hidroperoksida menghasilkan produk berupa aldehida, keton, asam, alkohol, komponen hidroksi, lakton, hidrokarbon, dienal, epoksida, dan senyawa polimer atau monomer yang diukur oleh nilai bilangan anisidin (Panagan et al. 2011). Hasil pengujian nilai $p$-anisidin sesuai dengan standar IFOS (2014), yaitu $\leq 20 \mathrm{mEq} / \mathrm{kg}$ (Figure 4). Nilai bilangan $p$-anisidin terendah terdapat pada suhu $50^{\circ} \mathrm{C} 1$ jam dan tertinggi pada suhu $70^{\circ} \mathrm{C} 3$ jam, berturut-turut yaitu 2,12-6,15 $\mathrm{mEq} / \mathrm{kg}$. Hal ini selaras dengan nilai anisidin dari nilai peroksida yang terbentuk akibat dekomposisi hidroperoksida. Waktu ekstraksi yang semakin lama, maka semakin tinggi nilai anisidin yang terbentuk (Yoshiara 2013). Waktu yang lebih lama menyebabkan proses dekomposisi berjalan maksimal dan banyak terbentuk oksidasi sekunder (Estiasih 2009)

\section{Bilangan Total Oksidasi}

Minyak ikan memiliki nilai peroksida yang cukup tinggi seiring dengan bilangan p-anisidin yang cukup tinggi, nilai tersebut menandakan bahwa kualitas minyak ikan yang rendah (Syari 2014). Syarat nilai total oksidasi yang dapat diterima yaitu $\leq 26 \mathrm{mEq} /$ $\mathrm{kg}$ (IFOS 2014). Total oksidasi merupakan penjumlahan antara dua kali bilangan peroksida (PV) dan nilai bilangan anisidin ( $p$-anisidin) yang terdapat pada minyak ikan. Nilai total oksidasi masing-masing

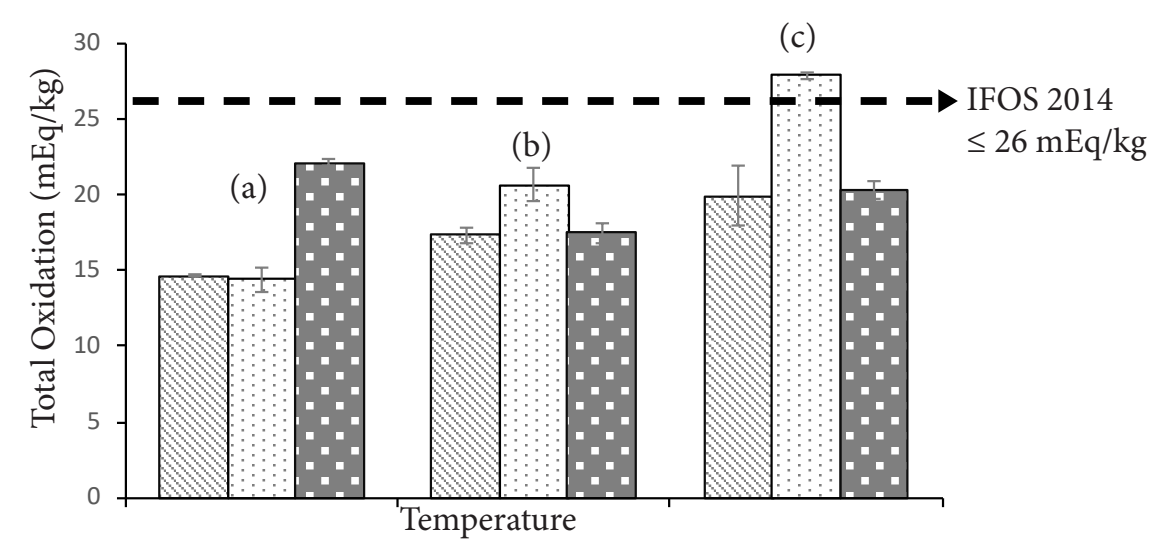

Figure 5 Effect of temperature and time on the total oxide of fish oil extraction using dry rendering method; (a) $50^{\circ} \mathrm{C}$; (b) $60^{\circ} \mathrm{C}$; (c) $70{ }^{\circ} \mathrm{C}$; $\mathrm{N}$ one hour; two hour; three hour. 
perlakuan sudah sesuai dengan standar IFOS (2014) yaitu $\leq 26 \mathrm{mEq} / \mathrm{kg}$, tetapi pada suhu $70^{\circ} \mathrm{C}$ selama 2 jam belum memenuhi yaitu $27,92 \mathrm{mEq} / \mathrm{kg}$ (Figure 5). Hal ini dapat disebabkan oleh penggunaan suhu tinggi, terpapar cahaya dan udara pada saat proses pengolahan, serta penyimpanan minyak ikan pada suhu ruang. Waktu penyimpanan dapat memengaruhi kualitas minyak ikan, semakin lama penyimpanan akan menyebabkan proses oksidasi semakin meningkat. Faktor lain yang memengaruhi nilai oksidasi yaitu suhu penyimpanan. Penyimpanan minyak ikan dengan suhu $-18^{\circ} \mathrm{C}$ memiliki daya simpan hampir dua kali lebih lama jika dibandingkan dengan minyak ikan yang disimpan pada suhu $4^{\circ} \mathrm{C}$ (Zuta et al. 2007).

\section{Profil Asam Lemak Minyak Ikan Hasil Ekstraksi}

Pengujian dilakukan pada minyak ikan terbaik yaitu ekstraksi suhu $50^{\circ} \mathrm{C}$ selama 2 jam, untuk menentukan kandungan asam lemak yang terdapat pada minyak ikan. Asam lemak yag diuji yaitu saturated fatty acid (SFA) berupa asam lemak yang tidak memiliki ikatan rangkap, monounsaturated fatty acid (MUFA) berupa asam lemak dengan ikatan rangkap tunggal, dan polyunsaturated fatty acid (PUFA) yaitu asam lemak tak jenuh majemuk. Profil asam lemak hasil eksraksi dapat dilihat pada Table 1.

Hasil pengujian profil asam lemak minyak ikan dengan ekstraksi dry rendering pada Table 1 cenderung didominasi oleh

Table 1 Fatty acid profile of fish oil extracted by dry rendering method method.

\begin{tabular}{|c|c|}
\hline Fatty Acid & Results $(\% \mathrm{w} / \mathrm{w})$ \\
\hline Laurat acid C12:0 & 0.70 \\
\hline Myristic acid C14:0 & 3.67 \\
\hline Pentadenoic acid C15:0 & 0.13 \\
\hline Palmitic acid C16:0 & 27.67 \\
\hline Heptadecanoic acid C17:0 & 0.10 \\
\hline Stearic acid C18:0 & 9.37 \\
\hline Arachidic Acid C20:0 & 0.14 \\
\hline Heneicosanoat Acid C21:0 & 0.03 \\
\hline Lignoceric AcidC24:0 & 0.08 \\
\hline SFA Total (Saturated Fatty Acid) & 41.89 \\
\hline Miristoleic Acid C14:1 & 0.02 \\
\hline Palmitoleic Acid C16:1 & 0.71 \\
\hline Cis-10- Heptadecanoic Acid C17:1 & 0.08 \\
\hline Oleic Acid C18:1n-9c & 33.11 \\
\hline Nervonic Acid C24:1 & 0.02 \\
\hline MUFA Total (Mono Unsaturated Fatty Acid) & 33.94 \\
\hline Asam Linoleic Acid C18:2n-6c & 11.01 \\
\hline Asam y-Linolenic Acid C18:3n-6 & 0.13 \\
\hline Cis-11,14-Eikosedienoat Acid C20:2 & 0.36 \\
\hline Cis-8,11,14-Eikosetrienoat acid C20:3n-6 & 0.47 \\
\hline Arachidonic Acid C20:4n-6 & 0.11 \\
\hline Ecosapentaenoic Acid (EPA) C20:5n-3 & 0.02 \\
\hline Cis-13,16- Docosadienoic Acid C22:2 & 0.02 \\
\hline Docosahexaenoic Acid (DHA) C22:6n-3 & 0.10 \\
\hline PUFA Total (Polyunsaturated Fatty Acid) & 12.22 \\
\hline Total Fatty Acids Identified & 88.04 \\
\hline
\end{tabular}


asam lemak oleat. Selaras dengan pernyataan Guler et al. (2008) bahwa karakteristik minyak ikan air tawar lebih didominasi oleh asam oleat dan palmitat, misalnya pada ikan mas. Hal ini sesuai dengan kandungan minyak ikan patin dalam Table 1 yaitu SFA $>$ MUFA > PUFA dengan kandungan asam lemak dominan adalah palmitat $(27,67 \%)$, oleat $(33,11 \%)$, dan linoleat $(11,01 \%)$. Kamini et al. (2016) melaporkan bahwa asam lemak dominan pada lemak jeroan patin yaitu oleat $(27,19 \%)$. Kandungan asam lemak sangat berpengaruh terhadap tingkat oksidasi pada minyak ikan yang dihasilkan. Proses oksidasi asam lemak sangat tergantung dari jumlah ikatan rangkapnya. Asam lemak jenuh (SFA) tidak memiliki ikatan rangkap sedangkan asam lemak tak jenuh (MUFA dan PUFA) memiliki ikatan rangkap sehingga mudah teroksidasi (Suseno et al. 2013). Asam lemak tak jenuh yang berikatan dengan oksigen bebas akan terbentuk hidroperoksida yang menunjukkan kemunduran mutu minyak. Tinggi kandungan hidroperoksida yang terbentuk akan menghasilkan bilangan peroksida yang tinggi. Bilangan peroksida meningkat seiring dengan kenaikan suhu dan lama waktu ekstraksi.

\section{Pemurnian Minyak Ikan Berdasarkan Karakteristik Oksidasi}

Pemurnian minyak ikan hasil ekstraksi terbaik yaitu pada suhu $50^{\circ} \mathrm{C}$ selama 2 jam. Proses pemurnian bertujuan untuk menghilangkan kontaminan yang dapat memengaruhi mutu minyak (Suseno et al. 2015). Minyak ikan patin hasil ekstraksi terbaik memiliki warna kuning keemasan dan berbau khas ikan patin. Hasil pemurnian menggunakan magnesol XL menunjukkan adanya perubahan pigmen dari warna kuning keemasan menjadi bening.

Pemurnian menggunakan magnesol
XL dapat menyerap komponen warna pada minyak, suspensi koloid (gum dan resin), dan hasil degradasi minyak, misalnya yang terjadi pada bilangan peroksida (Ketaren 2012). Magnesol atau magnesium silika merupakan kelompok absorben sintetik yang memiliki gugus fungsi terdiri dari $\mathrm{SiO}_{2}$ sebanyak 63,4\%, $\mathrm{MgO} 31,0 \%$ dan $\mathrm{H}_{2} \mathrm{O}_{4}$. Adsorben ini mampu melakukan pencegahan keberadaan material inaktif dan zat pengotor yang dapat memengaruhi aktivitas adsorpsi (Suseno et al. 2015). Magnesium silika juga sangat efektif dalam mengadsorbsi zat-zat organik. Sifat hidrofobik inilah yang mampu mengontrol dengan cara menarik kotoran yang bersifat hidrofobik sehingga saling berikatan dan membentuk gumpalan dengan partikel bahan pengotor lainnya.

Table 2 menunjukkan bahwa pemurnian menggunakan magnesol XL mampu menurunkan FFA, PV, $p$-AnV dan TOTOX masing-masing yaitu $38,47 \%, 53,13 \%, 33,11 \%, 48,06 \%$.Bilangan peroksida yang didapatkan sebelum dilakukan pemurnian belum memenuhi standar IFOS, diduga karena suhu yang semakin tinggi dan semakin lama ekstraksi menyebabkan oksigen yang terlarut dalam bahan semakin sedikit. Minyak ikan setelah pemurnian mengalami penurunan nilai bilangan peroksida sehingga memenuhi standar IFOS. Pemurnian dengan menggunakan magnesol XL ini mampu menurunkan bilangan peroksida (PV), FFA, p-AnV, dan TOTOX memenuhi standar IFOS (2014) yaitu asam lemak bebas $\leq 1,50 \%$, bilangan peroksida $\leq 5,00 \mathrm{mEq} / \mathrm{kg}$, nilai anisidin $\leq 20,00 \mathrm{mEq} / \mathrm{kg}$ dan total oksidasi $\leq$ $26,00 \mathrm{mEq} / \mathrm{kg}$. Persentase reduksi parameter oksidasi pada penelitian ini tidak berbeda jauh dengan penelitian Suseno et al. (2011) yaitu penggunaan magnesol pada minyak ikan sarden mampu menurunkan nilai PV 59.9\%. Perbedaan tersebut dapat disebabkan oleh perbedaan jenis sampel yang digunakan.

Table 2 Characteristics of pangasius fish oil before and after purification

\begin{tabular}{cccc}
\hline Characteristics & Fish oil before purification $^{1}$ & Fish oil after purification $^{2}$ & IFOS 2014 \\
\hline FFA $(\%)$ & $0.13 \pm 0.01$ & $0.08 \pm 0.03$ & $\leq 1.5$ \\
PV $(\mathrm{mEq} / \mathrm{kg})$ & $5.76 \pm 0.60$ & $2.70 \pm 0.20$ & $\leq 5.0$ \\
$\mathrm{p}-\mathrm{AV}(\mathrm{mEq} / \mathrm{kg})$ & $2.87 \pm 0.43$ & $1.92 \pm 0.63$ & $\leq 20$ \\
Totox $(\mathrm{mEq} / \mathrm{kg})$ & $14.40 \pm 1.94$ & $7.48 \pm 0.23$ & $\leq 26$ \\
\hline
\end{tabular}




\section{KESIMPULAN}

Metode ekstraksi dry rendering mendapatkan hasil terbaik pada suhu $50^{\circ} \mathrm{C}$ selama 2 jam dengan karakteristik minyak ikan yang dihasilkan yaitu memiliki nilai asam lemak bebas, bilangan $p$-anisidin, dan nilai total oksidasi sesuai standar IFOS 2014, sedangkan bilangan peroksida belum sesuai standar IFOS 2014. Pemurnian dengan proses bleaching menggunakan magnesol XL dapat meningkatkan kualitas minyak ikan sehingga sesuai standar IFOS 2014. Nilai yang diperoleh masing-masing yaitu $0,08 \pm 0,03 \%, 1,92 \pm 0,63$ $\mathrm{mEq} / \mathrm{kg}, \quad 7,48 \pm 0,23 \mathrm{mEq} / \mathrm{kg}$ dan $2,70 \pm 0,20$ $\mathrm{mEq} / \mathrm{kg}$.

\section{DAFTAR PUSTAKA}

[AOAC] Association of Official Analytical Chemist. 2005. Official Method of Analysis of the Association of Official Analytical of Chemist. Virginia (US): The Association of Analytical Chemist, Inc.

[AOCS] American Oil Chemists Society. 1997. Official method cd 8-53 peroxide value. cd18-90 p-anisidine value. cg 3-91 recommended practices for assessing oil quality and stability dalam Official Methods and Recommended Practices of the American Oil Chemists' Society. Urbana (US): AOCS Press.

[AOCS] American Oil Chemists Society. 1998. Free fatty acids dalam Official Methods and Recommended Practices of the American Oil Chemists Society. Vol 5a. 5th ed. Champaign: AOCS Press.

[BPS] Badan Pusat Statistik. 2017. Nilai ekspor impor minyak ikan. http://www.bps.go.id [diunduh 10 Januari 2020].

Chantachum S, Benjakul S, Sriwirat N. 2000. Separation and quality of fish oil from precooked and non-precooked tuna head. Food Chemistry. 69(3): 289-294.

Estiasih T. 2009. Minyak Ikan, Teknologi dan Penerapannya untuk Pangan dan Kesehatan. Yogyakarta (ID): Graha Ilmu.

Felix ML, Velazquez M. 2002. Current status of lipid nutrition white shrimp, Litopenaeus vannamei. Food Chemistry. 96: 36-45.

Guler GO, Kiztanir B, Aktumsek A, Citil OB, Ozparlak H. 2008. Determination of the seasonal changes on total fatty acid composition and 3/6 ratios of carp (Cyprinus carpio L.) muscle lipids in Beysehir Lake (Turkey). Food Chemistry. $108: 689-694$.

Harris WS, Mozaffarian D, Rimm E, Kris Etherton P, Rudel LL, Appel LJ. 2009. Omega 6 fatty acids and risk for cardiovascular disease: a science advisory from the American Heart Association Nutrition Subcommittee of the Council on Nutrition, Physical Activity, and Metabolism; Council on Cardiovascular Nursing; and Council on Epidemiology and Prevention. Circulation. 119(6): 902917.

Hastarini E, Fardiaz D, Irianto HE, Budijanto S. 2012. Karakteristik minyak ikan dari limbah pengolahan filet ikan patin siam (Pangasius hypopthalmus) dan ikan patin jambal (Pangasius djambal). Jurnal Agritech. 32(4): 403-410.

[IFOS] International Fish Oil Standard. 2014. Fish oil purity standars. [diakses pada 25 Maret 2019]. Tersedia di : www. Omegavia.com/best.

Kamini, Suptijah P, Santoso J, Suseno SH. 2016. Ekstraksi dry rendering dan karakterisasi minyak ikan dari lemak jeroan hasil samping pengolahan salai patin siam (Pangasius hipopthalmus). Jurnal Pengolahan Hasil Perikanan Indonesia. 19(3): 196-205.

Ketaren S. 2012. Pengantar Teknologi Minyak dan Lemak Pangan. Jakarta (ID): UI Press.

[KKP] Kementerian Kelautan dan Perikanan. 2018. Data produksi ikan patin. [diakses pada 14 November 2019]. Tersedia di : http://kkp.go.id.

Memon NN, Talpur FN, Sherazi STH, Bhanger MI. 2010. Impact of refrigerated storage on quality of oil from freshwater jarko (Wallago attu) fish. Pakistan Journal of Analytical Environmental Chemistry. $11(2): 37-43$.

Nugroho AJ, Ibrahim R, Riyadi PH. 2014. Pengaruh perbedaan suhu pengukusan (steam jacket) terhadap kualitas minyak dari limbah usus ikan nila (Oreochromis niloticus). Jurnal Pengolahan dan Bioteknologi Hasil Perikanan. 3(1):21-29.

Orban E, Teresina N, Gabriella DL, Maurizio 
M, Irene C, Loretta G, Roberto C. 2008. New trends in the seafood market. Sutchi catfish (Pangasius hypophthalmus) fillets from Vietnam: Nutritional quality and safety aspects. Food Chemistry. 110(2): 383- 389.

Panagan A, Heni Y, Jojor UG. 2011. Analisis kualitatif dan kuantitatif asam lemak tak jenuh omega-3 dari minyak ikan patin (Pangasius pangasius) dengan metode kromatografi gas. Jurnal Pendidikan Sains. 14(4) : 38-42.

Sartika RAD. 2009. Pengaruh suhu dan lama proses menggoreng (deep frying) terhadap pembentukan asam lemak trans. Makara Sains. 13(1): 23-28.

Suseno SH, Tajul AY, Wan Nadiah WA. 2011. Improving the quality of lemuru (Sardinela lemuru) oil using magnesol XL filter aid. Indonesian Fisheries Research Journal. 18:255-264.

Suseno SH, Izaki AF, Suptijah P, Jacoeb AM, Saraswati. 2013. Kinetic study of free fatty acid adsorption using adsorbent in Sardine (Sardinella sp.) oil refining. Asian Journal of Agriculture and Food Sciences. 1(5):287-293.

Suseno SH, Nurjanah, Yoshiara, Saraswati. 2015. Determination of extraction temperature and period of fish oil from tilapia (Oreochromis niloticus) by product using wet rendering methode. The 1st International Symposium on Aquatic Product Processing. 1:125-135.

Syari C. 2014. Pengaruh wet rendering terhadap kualitas minyak ikan siro (Amblygaster sirm). [Skripsi]. Bogor (ID): Institut Pertanian Bogor.

Thammapat P, Raviyan P, Siriamornpun S. 2010. Proximate and fatty acids composition of the muscles and viscera of Asian catfish (Pangasius bocourti). Food Chemistry. 122(1): 223-227.

Weber J, Bochi VC, Ribeiro CP, Victorio AM dan Emanuelli T. 2007. Effect of different cooking methods on oxidation. Journal of Food Chemistry.106:140-146.

Wu TH dan Peter JB. 2008. Salmon by-product storage and oil extraction. Journal of Food Chemistry.111(08):868-871.

Yoshiara. 2013. Penentuan suhu dan waktu pada ekstraksi wet rendering minyak dari by-product ikan nila (Oreochromis niloticus) [Skripsi]. Bogor (ID): Institut Pertanian Bogor.

Zuta PC, Simpson, Zhao, Leclerc. 2007. The Effect of $\alpha$-tochopherol on the oxidation of mackerel oil. Food Chemistry. 100:800807. 